\title{
Geographical Indications in Trade Commodities for Promoting Sustainable Economic Development in Indonesia
}

\author{
Dwi Tiara Kurnilasari \\ Gadjah Mada University, Indonesia \\ dwitiara96@mail.ugm.ac.id
}

\begin{abstract}
The recent COVID-19 pandemic has disrupted many countries. It leads them to imbalance conditions in various sectors, particularly in the economic sector due to the shifting of people's habits. Amidst the recession, Indonesian local horticulture commodities increase in rates, supporting Indonesia's revenue. In Indonesia, abundant natural resources with numerous potential Geographical Indications (GI) need the government and other related parties' intense role. It currently results in weakness in many ways to support sustainable economic development. This study aims to discuss the protection of Geographical Indications both in national and international laws and analyze certain vital steps to efficiently utilizing Indonesia's GI as trade commodities. The paper will mainly discuss Geographical Indication legal protection and ways to utilize it for the country's economy. The study finds that the legal protection of GI in Indonesia is still considered weak and lacks in parties' active involvement in managing GI-based trade commodities and products. The research concluded that to strengthen GI protection in Indonesia, related party involvement and continuous monitoring and promoting are necessary to be done. Furthermore, the advice is to increase local community awareness by government and non-governmental organizations toward GI potential. It includes developing an efficient protection and management system that fully maximized each party's ability to execute its responsibility.
\end{abstract}

KEYWORDS: Geographical Indications, Intellectual Property, Economic Development.

Copyright $\odot 2020$ by Author(s)

This work is licensed under a Creative Commons Attribution-ShareAlike 4.0 International License. All writings published in this journal are personal views of the authors and do not represent the views of this journal and the author's affiliated institutions.

\section{HOW TO CITE:}

Kurnilasari, Dwi Tiara. "Geographical Indications in Trade Commodities for Promoting Sustainable Development in Indonesia” (2020) 7:3 Lentera Hukum 279-300.

Submitted: August 31, 2020 Revised: November 09, 2020 Accepted: November 16, 2020 


\section{INTRODUCTION}

The current global pandemic caused by the massive spread of Severe Acute Respiratory Syndrome coronavirus2 (SARS-CoV-2), commonly known as COVID-19, has impacted various life sectors and brought immense change to them. ${ }^{1}$ One of the most significant impacted fields is the economic field being shadowed by potential upcoming recession for the next few quarters. Some countries even already declared their recession due to negative economic growth. One factor influencing the global recession is the transformation in social habit due to the implemented government's policy to tackle the COVID-19 sporadic transmission. This alteration of society habit has collided with particular business categories and causing economic growth to slow down to show a negative figure. ${ }^{2}$

Amidst the global recession issues that swept many countries, Indonesia also becomes one of the potential victims due to the negative economic growth caused by the COVID-19 pandemic. ${ }^{3}$ However, as if an anomaly being happened, Indonesia's export rates increase rapidly during the pandemic. Specifically, it comes from the horticulture sector. It successfully attains Indonesia's position as the central supporting economic growth sector in the 2020 second quarter. From January to May 2020, the fruits' export was drastically raised and accounted for 375 thousand tons. This figure indicates a steep rise of 31.89 percent in the horticulture field than the last term. ${ }^{4}$

One of the export commodities with massive demand during the pandemic is the North Sumatera's sweet corn. This commodity's export volume hit the amount of 111 tons in the first 2020 semester. Thus, it results in economic value as much as US\$ 82,000 billion, surpassing 91 tons volume in general. Fruits' export rates also have a sharp peak to 73.4 percent compared to previous years. Indonesian authentic fruits and vegetables are strongly believed to be the central pillar of future economic growth for few periods ahead. ${ }^{5}$

Annually, from January to December 2018, Indonesia's export valuation has accounted for as much as US\$168,83 million (US\$153,08 million from non-oil and gas; US $\$ 15,74$ million from oil and gas). On the 2019 annual trade statistics, a slight decrease has cut the valuation of Indonesia's export activities from the previous amount to US\$ 167,53 million (US\$ 154,09 million from non-oil and gas; US\$ 12,54 million from oil and gas). Due to the pandemic, 2020 annual trade activities did not bring good results than previous years. From January to September 2020, Indonesia's export valuation declined as much as 5,81\% (US $\$ 117,19$ million) than the same period last year from January to September 2019. Despite constant declining yearly export rates,

1 Lukasz Sulkowski, "Covid-19 Pandemic, Recession, Virtual Revolution Leading to De-globalization?" (2020), 12:1, Journal of Intercultural Management at 3, DOI: <10.2478/joim-2020-0029».

Ibid at 4.

3 UGM, "UGM Expert: Indonesia Imperilled Recession If Government is Dilatory on Handling Covid19", Universitas Gadjah Mada (16th July 2020), online: 〈ugm.ac.id〉.

4 CNN Indonesia, "Permintaan Ekspor Buah Naik Pesat Selama Pandemi Corona," CNN Indonesia (10 August 2020), online: 〈www.cnnindonesia.com〉.

5 CNN Indonesia, "Airlangga Sebut Buah-buahan Bisa Jadi Tumpuan Ekonomi RI," CNN Indonesia (10 August 2020), online: 〈www.cnnindonesia.com〉. 
Indonesia's non-oil and gas field was always scored surplus for the last three years. They were ranging from US\$ 3,84 million in 2018, US\$ 6,15 million in 2019, and US\$ 18,18 million in 2020. These numbers define Indonesia's high export rates in this sector and the importance of the non-oil and gas sector as one of the main pivots to support the country's economic development. ${ }^{6}$

The increasing demand for horticulture commodities in the international market indicates the considerable potential of Indonesia's export commodities, specifically in non-oil and gas fields. According to the statistical number of Indonesia's international trade, non-oil and gas fields, particularly agriculture and other business categories such as textile, accounted for $90.64 \%$ of the country's trade volume. ${ }^{7}$ Thus, the government needs to manage and utilize these sectors to the fullest to achieve the country's sustainable economic development goals.

One of the familiar terms usually linked with natural resources as export commodities is geographical indications (GI). By shaping the potential resources into GI products, Indonesia will improve economic value and price multiple times. It will also multiply its revenue through international trade activities and GI's local origin advancement into cultural tourism sites that attract people worldwide. ${ }^{8}$ Indonesia's massive potential does not come along with a high level of awareness from indigenous people in registering their GI to be protected by Indonesian laws legally. The number of Indonesian citizens with registered GI in 2018 was only 57 products amongst hundreds of traditional-based products. ${ }^{9}$ Compared to other Asian countries with the highest number of registered GI, China as an example, have registered as much as $8.507 \mathrm{GI}$ product into the World Intellectual Property Organization (WIPO) database. ${ }^{10}$

One of the particular cases regarding GI registration benefits for traditional knowledge-based products is Kintamani Bali Coffee, the first Indonesian GI registered product. The popularity of Kintamani Arabica Coffee has echoed to the level of international communities. This is evidenced by the high export requests for this specific coffee from numerous countries, mostly European countries. Due to its taste uniqueness, there are great possibilities for Kintamani Coffee to increase its market share in the European region, ${ }^{11}$ Hence, the Indonesian government must give further

6 Ministry of Trade, "Infografis Perkembangan Perdagangan Luar Negeri," Portal Statistik Perdagangan (September 2020), online: 〈statistik.kemendag.go.id).

7 Fifi Nofrida et al., Statistik Perdagangan Luar Negeri Indonesia Ekspor 2018 Jilid 1, (Jakarta: CV. Petratama Persada, 2018) at 7-13.

8 Ministry of Law and Human Rights, "Tingkatkan Devisa Negara dengan Indikasi Geografis," Kementerian Hukum dan Hak Asasi Manusia (8 November 2016), online: 〈www.kemenkumham.go.id〉.

9 Imam Lukito, "Peran Pemerintah Daerah dalam Mendorong Potensi Indikasi Geografis (Studi pada Provinsi Kepulauan Riau)" (2018) 12: 3 Jurnal Ilmiah Kebijakan Hukum at 315, DOI: 〈http://dx.doi.org/10.30641/kebijakan.2018.V12.313-330〉.

10 Republika, "RI Didorong Daftarkan Produk Indikasi Geografis," Republika (8th July 2019), online: 〈republika.co.id〉.

11 Hananto, P.W.H., and Rahandy, "The Urgency of Geographical Indication as a Legal Protection Instrument Toward Traditional Knowledge in Indonesia" (2019) 15:1 Law Reform at 65 - 66, DOI: 〈https://doi.org/10.14710/lr.vl5il.23355〉. 
attention to developing and advancing the Indonesian GI protection, utilization, and management system.

This study aims to examine the GI legal protection under Indonesian and international laws. It also aims to analyze certain measures to utilize Indonesia's GI as trade commodities efficiently. The main discussion of this article is the utilization of GI to support Indonesia's sustainable economic development. Two problems that will mainly be addressed in this article are: First, how is the protection of GI according to the Indonesian law system and international law? Second, how is the utilization of GI as export commodities to support Indonesia's sustainable economic growth? The first part of this article will generally elaborate and examine GI and its protection under national and international laws. The second part will compare GI's protection in three countries with the highest number of registered GI in the world. The last part will extensively conclude about crucial things that should be done by related parties in the GI management project to create an efficient and comprehensive protection system.

\section{GEOGRAPHICAL INDICATIONS AND FURTHER LEGAL PROTECTION}

A. Geographical Indications As an Intellectual Property Rights

GI becomes one of the intellectual property regime branches. The Agreement on TradeRelated Aspects of Intellectual Property Rights (TRIPs) states that GI is an indication used to identify a good originating from a member's territory or a region or locality in a certain territory. It carries a given quality, reputation, or other distinguishing characteristics strongly associated with its geographical origin. ${ }^{12}$ In Article 1 of Indonesian Law No. 20 of 2016 on Trademark and Geographical Indications, GI is a sign showing the geographical origin of goods and product due to the geographical factors, including natural and human factors, or their combination impacted in giving a certain reputation, qualities, and characteristics to the goods and produced products. ${ }^{13}$

The goods and products registered in the GI system are, but not limited to, agricultural products, handicrafts, and even other goods. Additionally, the good registered in General Registration of GI (Daftar Umum Indikasi Geografis) cannot be transferred into public-owned good. GI marks can only be used for the goods and products that have fulfilled specific requirements regulated in Specification Books (Buku Persyaratan).${ }^{14}$ The unique trait of the GI protection system is its strong link with the geographical factors of the goods. This geographical factor provides GI unique characteristics and becomes the embodiment of its owner indigenous culture. Furthermore, GI's high economic value is also one of the highlighted reasons for the importance of its protection. From an international perspective, GI comes from the importance of parties to protect their goods that carry specific geographical traits from

12 Primadiana Yunita, HAKI dan Masyarakat Ekonomi ASEAN (Malang: Cempluk Aksara, 2019) at 151.

13 The Indonesian Law 2016 Number 20 on Trademark and Geographical Indications, 2016, Art 1 Para 6.

14 Abdul Atsar, Mengenal Lebih Dekat Hukum Hak Kekayaan Intelektual (Yogyakarta: Penerbit Deepublish, 2018) at 23-24. 
their origin. Hence, referred to Indonesia's massive potential in the GI field, it is indeed essential to protect it from irresponsible parties. ${ }^{15}$

Unlike the Indication of Origins, GI is applied to show its origin and manifest its high standard and qualities that belong to a specific niche market. ${ }^{16}$ Moreover, GI also can act as an efficient business strategy where its registration and certification will indicate authenticity and specialty, which will lead to value addition. ${ }^{17}$ GI has its unique traits than other intellectual property rights, which are: (a) its name that should, though not mandatory, indicate a geographical origin for identifying and distinguishing GI products from others; (b) the territorial factor in GI is not necessarily meant as de jure territorial but defined as de facto or its actual geographical condition and location; (c) the ownership right of GI is not private ownership but collective ownership that owned communally by people in one area. Thus, its right is only limited to the right to use; and (d) quality, reputation, or other characteristics surrounding GI only acts as an alternative. The good would only need to fulfill one of these elements. ${ }^{18}$

\section{B. The Correlation Between GI and Trade Mark}

Amongst all of the branches in intellectual property law, GI has the closest resemblance with Trademark law. The regulation regarding GI is usually under one branch with Trademark law. It is not only the case in Indonesia but in most countries. Even in Indonesia's legal framework, GI is outlined in the same law with a trademark: Law No. 20 of 2016 on Trademark and Geographical Indications. Thus, the progression of GI development actually cannot be separated from the trademark law.

From a business's perspective, both GI and trademarks can be a distinctive sign for a specific product commonly used as essential branding tools. A brand image of a product is built and developed by using GI or trademark identities. While GI distinguishing goods from other geographical places, trademarks distinguish them from similar goods or services originating from other enterprises or companies. Both GI and trademarks can help develop a brand image and build a specific reputation that leads to the psychological relationship between consumers and goods. This term is called "brand loyalty," which is a significant power that a brand hold.

Due to their similarity, GI and trademarks' usage correlates with each other and shares many resemblances. However, these similarities differ on their own. For instance, the exclusive rights of GI and trademarks can be transferred to other parties through licensing. The difference lies in the parties who can acquire the license right.

15 Sujiana Donandi, Hukum Hak Kekayaan Intelektual di Indonesia - Intellectual Property Rights Law in Indonesia (Yogyakarta: Penerbit Deepublish, 2019) at 88.

16 Yunita, supra note 12 at 35.

17 Candra Irawan, "Pendaftaran Indikasi Geografis Sebagai Instrumen Perlindungan Hukum dan Peningkatan Daya Saing Produk Daerah Di Indonesia" (2017) Seminar Nasional Multi Displin dan Call For Papers Unisbank Ke 3 at 359, DOI: 〈https://doi.org/10.11ll/jwip/12073〉.

18 Rian Saputra, Adi Sulistyono \& Emmy Latifah, "Permohonan Internasional Sebagai Upaya Perlindungan Indikasi Geografis Indonesia Dalam Perdagangan Global (Studi Peraturan Pemerintah Nomor 22 Tahun 2018)" (2019) 7:2 Jurnal IUS: Kajian Hukum Dan Keadilan at 240, DOI: 〈http://dx.doi.org/10.29303/ius.v7i2630〉. 
On the one hand, a GI tells consumers a certain characteristic of goods is obtained due to their unique geographical traits. Hence, all producers who run their business in that area and produce the goods that share typical qualities and meet certain standards can use it. Producers from outside of the territory may not use it even if their product's qualities are the same or better due to GI exclusive rights granted to local groups. On the other hand, a trademark used by an enterprise distinguishes its goods and services from others. It can be assigned or licensed to anyone worldwide, as long as the parties fulfilled their license contract. It is because trademarks themselves are linked to a specific company and not to a particular place. ${ }^{19}$

The exclusiveness in GI licensing makes it more challenging to register trademarks that contain geographical names than general trademarks. This is because a trademark with a geographical name in it will represent all potentially interested parties involved. Another approach commonly used to tackle this problem is using a graphic logo. It refers to the area rather than using a plain geographical name as one of its brand names. Rather than a geographic wordmark, the graphic trademark is then filled as a collective mark for goods produced from the area's members. ${ }^{20}$

There are some important aspects of linking GI and trademark law. First, trademark application and GI registration application correlates in a relationship called mutatis mutandis as stated in Article 53 (4) Law No. 20 of 2016 on Trademark and Geographical Indications: ${ }^{21}$ Second, terms and procedure of trademark's lawsuit also applies as mutatis mutandis with GI's lawsuit. Third, the legal enforcement of trademark law closely resemblance and even has few similarities with the enforcement of GI law. Thus, GI has the closest alikeness and correlation with trademark law.

\section{The Advantage of GI Utilization as International Trade Commodities}

The benefit of the GI utilization is not merely as an indication of the goods' origin. If GI is utilized appropriately and efficiently, the advantages will be fruitful for the government and the indigenous people. First, an efficient and precise GI usage will result in positive economic and social growth for its group owner. Generally, a traditional-based product will usually create its niche market with its loyal customers. However, using GI as additional protection would significantly impact, such as handing a better chance for the local product to compete in the international market. The utilization of GI also provides an equal chance for large-scale enterprises or small and medium-scale enterprises to participate in the GI goods production chain fairly. Moreover, it will also impact increasing regional's revenue both directly and indirectly. ${ }^{22}$ GI will help small and medium enterprises to scale up both their business

19 The Coffee Guide, "Trademarks versus Geographical Indications," The Coffee Guide: Trade Practices of Relevance to Exporters in Coffee-Producing Countries (30th June 2012), online: 〈thecoffeeguide.org〉

20 Ibid.

21 Indonesian Law, supra note 13 at Art 53 Para 4.

22 Giovanni Belletti, Andrea Marescotti \& Jean-Marc Touzard, "Geographical Indications, Public Goods, and Sustainable Development: The Roles of Actors' Strategies and Public Policies" (2017) 98 World Development at 47, DOI: 〈https://doi.org/10.1016/j.worlddev.2015.05.004〉 
and its product quality. Additionally, growing numbers of ASEAN countries have proved GI's ability to raise local communities' living standards through their economic power. ${ }^{23}$

Second, GI can add value to local products in protecting their uniqueness simultaneously. GI also allows the producers to consolidate their selling price in the market to raise its price due to the high quality and famous reputation in its field. GI products' excellent reputation can even help them to penetrate a new market and scope. ${ }^{24}$ GI certified products' particular character also can distinguish itself from its regular unbranded competitor in the same category. GI acts as the symbolization of locality, authenticity, and local people tradition. By registering their products into the GI regime, producers can market it to a special group of loyal consumers willing to pay more to attain a specialty product. ${ }^{25}$ Third, due to its strong link with its origin and culture, GI will also play a role in promoting local culture to various social groups. The utilization of GI is also believed to draw a new perspective for government both at the national or local level regarding policymaking regarding the protection and promotion of local cultural heritage. ${ }^{26}$ GI utilization in Indonesia has brought a substantial impact on the increase of Indonesian specialty coffee export rates.

Indonesian has been known as a haven for specialty coffee. Hence, Indonesia's number of coffee exports is closely related to the local's specialty coffee market share. Since the Kintamani Coffee GI registration was accepted in 2008, other local's coffee producers also started registering their products as one of Indonesia's GI goods. This increasing number of specialty coffee registered in the GI system resulting in the enhancement of coffee commodity value in the international market. Even though the total amount of its export shifts unpredictably, its valuation keeps increasing due to the high reputation and qualities as the benefit of registering goods in the GI system. By referring to this chart, GI's utilization in other sectors commodities should become one option for improving Indonesia's revenue, and it supports Indonesia's sustainable economic development.

\section{Geographical Indications in Indonesia}

GI is a relatively new concept in the intellectual property field. It generally links with other terms called indications of origin and appellation of origin. Indication of origins is every expression or sign used to indicate products, goods, or services cultivated in a

23 Ai Tashiro, Yuta Uchiyama \& Ryo Kohsaka, "Internal Processes of Geographical Indication and Their Effects: An Evaluation Framework for Geographical Indication Applicants in Japan" (2018) 5:3 Journal of Ethnic Foods at 202, DOI: 〈https://doi.org/10.1016/j.jef.2018.07.004〉.

24 Lukito, supra note 9 at 319.

25 Thanasis Kizos, et al., "The Governance of Geographical Indications: Experiences of Practical Implementation of Selected Case Studies in Austria, Italy, Greece and Japan" (2017) 119:12 British Food Journal at 2864, DOI: 〈https://doi.org/10.1108/BFJ-01-2017-0037〉.

26 Irene Calboli \& Delphine Marie-Vivien, "One Size Does Not Fit All: The Roles of the State and the Private Sector in the Governing Framework of Geographical Indications" (2018) 24 The Cambridge Handbook of Public-Private Partnerships, Intellectual Property Governance, and Sustainable Development at 312, DOI: 〈https://doi.org/10.1017/9781316809587.017〉. 
country, region, or certain area. Meanwhile, the appellation of origin, defined as a geographical name from one country, region, or a certain area, is used to show where a product originated. Its specific trait either exclusively or essentially related to its geographical environment, including natural factors or human factors, or even the combination of both. Hence, the origin's appellation carries the vital link between products' quality and their originated production area. ${ }^{27}$

Indonesia's GI protection falls into a group of sui generis protection system. As mentioned earlier, the GI protection is still outlined under the same law as a trademark: Law No. 20 of 2016 on Trademarks and Geographical Indications. GI is placed explicitly in Chapters VIII to XI, spanning from the protection, registration to the extent of developing and monitoring trade commodities and GI registered products. There are also additional regulations as the implementation guidelines for legal enforcements. One of those guidelines is the Ministry of Law and Human Rights Regulations No. 12 of 2019 on Geographical Indications. It especially addresses GI provisions in Indonesia's jurisdiction, but with a few additional articles which one of which is regarding GI registration in other countries.

GI international registration is essential to be regulated in Indonesia due to its benefits, which are: (a) other countries will also precisely know the information about registered goods; (b) the state members will be asked to respect and protect each other GI; (c) GI goods will still be protected as long as it is protected in its originated country and there is no change toward it; (d) in the producer's perspective, GI goods that have been registered and protected under the Treaty of Lisbon will extensively increasing its quality and price on the international market; (e) from the consumer's point of view, a GI certification marks will guarantee its authenticity and quality, hence the customers will not be misinformed about the goods' origin. ${ }^{28}$

Another regulation used as a legal basis for GI management is Government Regulation No. 45 of 2016, amending Government Regulation No. 45 of 2014 on Classification and Tariff for Country Non-Tax Revenue in the Ministry of Law and Human Rights. This regulation does not provide a proper explanation nor protection to GI. Rather, it merely states that the registration of intellectual property that belongs and came from Indonesia can increase its revenue through non-tax revenue. Given the minimum progression in Indonesia's GI field despite its vast capability to scale up economic growth, GI policy and management should be included in future policy development agendas both for government and other related parties.

\section{E. Geographical Indications in International Law}

Long before TRIPs came into force, GI, Indications of origin, and appellation of origin already had their regulation among the international communities and merchants. Nevertheless, this regulation merely depended on parties' mutual agreement on whether implemented or not. The first multilateral agreement on GI was the Paris

27 Achmad Zen U.P, Hak Kekayaan Intelektual Pasca TRIPs (Bandung: PT. Alumni, 2011) at 77.

28 Saputra, supra note 18 at 246. 
Convention for the Protection of Industrial Property in 1883. It provided the protection for origin and appellations of origin as industrial property rights. In Article 9 (1) of this agreement, every commodity that used a legally protected trademark and name belongs to other goods illegally can be put on hold due to it. ${ }^{29}$ In 1891, a multilateral agreement Madrid Agreement for the repression of false or deceptive indications of the source of goods was held to prohibit the use of forged and deceptive indication of origin. The previous convention, the Paris Convention, also prohibited the members from using a false GI. The state parties later signed the agreement and amending the treaty into the 1891 Madrid Agreement. This agreement had more specific regulations to the extent of classifying the intellectual property infringement group. ${ }^{30}$

Additionally, other than conventions generally protecting indications of origin, there was a specialized convention on the indication of origin of cheese products that usually became one of the trade commodities. In 1951, the International Convention on the use of appellations of origin and denominations of cheeses, commonly known as the Stresa Convention, was legalized. The member of this convention was European countries which are the largest cheese producer in the world. The convention was initially intended to ban and suppress appellation of origin in each of their legal territories in other languages or its original language., in Articles 2-9 of this convention. Enforced on $1^{\text {st }}$ September 1953, the Stresa Convention became legally binding for all of the parties. It classified actions by providing false information regarding the origin, type, and special quality from cheese products and other liked products that could be misinterpreted as cheese products. ${ }^{31}$

Five years after the Stresa Convention was signed, the Lisbon Agreement for protecting appellations of origin and their registration in 1958 became the first stepping stone of GI protection before TRIPs. The Lisbon Agreement has formed an international registration system between its parties to protect their appellation of origin. However, this agreement failed to get approval from most of its members. 28 members only signed it even after September 2013. One of the main reasons for the Lisbon Agreement's failure was the given protection limited to only certain countries. The Lisbon Agreement did not allow any exceptions for GI that has been commonly regulated between the state members. ${ }^{32}$

The idea to protect GI has expanded to the largest wine-producing countries, leading to the International Wine Organization's establishment by the French Society for Encouraging Agriculture in 1922. This organization aims to protect its members' authentic wine products and widely represent the wine industry's specialty. This organization then held its conference in Genoa (1923) and Paris (1924). On 29th November 1924, Spain, Tunisia, French, Portuguese, Hungary, Luxembourg, Greece, and Italy signed the International Office of Vine and Wine (OIV) establishment in

29 Michael Blakeney, The Protection of Geographical Indications: Law and Practice (Cheltenham: Edward Elgar Publishing Limited, 2014) at 10.

30 Ibid at 11 .

31 Ibid at 13.

32 Ibid at 14-15. 
Paris. OIV was then formed as de facto on 3rd December 1927 after its ratification from 5 countries. Based on its regulations, OIV responsible for guaranteeing wine products' appellation of origin protection..$^{33}$

After countless predecessor conventions and agreements, the WTO finally formed an international GI regulation due to European countries' primary demand in the GATT Uruguay Round. Chapter VII of the TRIPs Agreement covers four main themes: i) GI protection; ii) GI and Trademarks; iii) Special GI Protection for wine and spirits and; 4) Summary of the previous parts. Based on the TRIPs Agreement, a protected GI should have indication marks. However, it does not necessarily include a certain geographical name of a place on the Earth. For instance, Indian Basmati Rice indicated its origin from India even though Basmati has no place. The meaning of indication is that it should have to carry a unique point that shows its origin. ${ }^{34}$ The TRIPs Agreement also states that GI can be in the form of a name or symbol that is publicly known. Every mark that can be utilized directly to show its territoriality may also be included as GI. Because GI encompasses its origin place and the reputation and other unique characteristics tagged along with it, GI's distinguishing factor should always be shown as if it is needed. ${ }^{35}$

\section{GEOGRAPHICAL INDICATIONS' ADVANCEMENT AND UTILIZATION IN OTHER COUNTRIES}

\section{A. Germany}

As the country with the highest number of registered GI globally, Germany has established the GI protection organized more perfectly. Germany's GI regulatory framework does not only cover the authorized institution but also to the extent of affiliated parties' potential conflict prevention. The commissioned institution responsible for enforcing GI regulation in Germany is the Federal Ministry of Justice and Consumer Protection (Bundesministerium der Justiz und für Verbraucherschutz-BMJV), collaborating with the Federal Ministry of Food and Agriculture (Bundesministerium für Ernährung und Landwirtschaft - BMEL). In general, BMJV is responsible for regulating GI matters and is assigned to performing comestibles GI registration and protection when working hand in hand with BMEL. Particularly for wine, spirits, and aromatized wines protection, BMEL is the only fully authorized institutions in this field. ${ }^{36}$

Germany is a federal state with 16 states known as Länder. Every states' authority is being decentralized from the Federal Government responsible for policy and regulation-making matters. Meanwhile, each Länder has full authority in every regulation and legal enforcement in their States. In Germany's Trademarks Act

33 Ibid at 17 .

34 Ibid at 21 .

35 Jessica C Lai, Indigenous Cultural Heritage, and Intellectual Property Rights: Learning from the New Zealand Experienced (Lucerne: Springer International Publishing, 2014) at 118-119.

36 Protection and Control of Geographical Indications for Agricultural Products in the EU Member States (Alicante: European Union Intellectual Property Office) at 65. 
(Markengesetz-MarkenG), each state has the right to investigate every GI application and even the registered ones, forming control bodies and involving them in every GI application inspection. ${ }^{37}$ As for wine and aromatized wine base GI products, Germany has a sui generis system based on the German Wine Act (Wengesetz-WeinG) along with Control Authorities. They are responsible for monitoring each chosen wine inspector in performing their duties. The inspector and authorized bodied should exchange information and collaborating when the GI inspection is being held. Suppose there is any mismatch, or potential misappropriation found out during the investigation process. In that case, the inspectors should inform their findings to Control Authorities. Based on Wine Surveillance Regulation (Wein-überwachungsverordnung - WeinÜV), the State Government with the highest administration position will be the one who chooses the official assigned for monitoring producer who infringed the GI. ${ }^{38}$

In the German sui generis GI protection system, there are two kinds of punitive measures for every GI misappropriation. They are administrative sanctions and penal sanctions. Control authorities are involved in official controls that have legal powers to take action in cases of non-compliance and with the requests from control bodies who will establish a regulatory fine of up to EUR 10.000. The responsibility for applying administrative sanctions is assigned to the highest responsible Länder. ${ }^{39}$ According to Article 144 of the MarkenG, anyone in the course of trade unlawfully uses a GI, a name, an indication, or a sign to exploit or impair the reputation or distinctive character will be punished with up to two years imprisonment or a criminal fine. ${ }^{40}$

In general, both Germany and Indonesia have a similar GI protection system that shares many resemblances. However, compared to Indonesia's GI protection, Germany distributes each parties' authority evenly. Hence, the main idea of decentralization in GI management is successfully achieved by them. In Germany, each Länder has a considerable role and participated actively, not only in GI law's legal enforcement. Germany also implements a full authority scheme for each Länder to manage its GI goods. Due to the local government's familiarity and knowledge regarding the local's culture, this method will be more beneficial and efficient in GI protection.

Moreover, every GI misappropriation of Germany's GI goods will be carefully examined by control authorities that consist of experts in the related field. Thus, the investigation process can be more thorough because GI-related lawsuit usually involves more than one field that sometimes is not in the scope of law arena. In contrast, GI lawsuit in Indonesia is classified in the same group as other intellectual property lawsuits. However, not every legal enforcement in practice has a broad knowledge in the intellectual property field. Hence, assigning an expert team with a legal enforcer to investigating GI-related lawsuits can better implement GI regulation.

Ibid at 66.

Ibid at 67.

39 Ibid at 71.

40 Ibid. 


\section{B. China}

Widely known as the Asian Tiger dominating the international trade market, especially in Asia, China also becomes an Asian country with the highest registered GI. The Chinese government's high awareness of this issue is parallel with the vast potential in unique agricultural products and goods. From the agriculture sector, China has registered as many as 2533 GI agricultural products from 2017 to 2018. The goals of registering their GI is not solely due to the urgency of GI protection, but also to expand every commodities' market access both domestically and internationally through enhancement of quality. From China's perspective, GI utilization is not a short-term economic plan but a plan that should be carefully designed to be beneficial for a long time. ${ }^{41}$

China's GI protection system adapts from the French GI protection system. It uses two legal protection types, using trademark law and sui generis law. This protection model is an amendment and advancement from the previous system relying on trademarks and trade commodities certification. Some provinces in China even have their GI protection system, which unfortunately collided with each other. ${ }^{42}$ Furthermore, three official bodies with authority to accept GI registration applications are the General Administration of Quality Supervision, Inspection, Quarantine (AQSIQ), the Ministry of Agriculture, and the State Administration for Industry and Commerce (SAIC). Due to the three institutions' collaborative role, China's GI Protection can align with the sui generis system in its implementation. On the one hand, the sui generis system protected GI permanently. On the other hand, protection through trademark will only be granted 10 years of protection to reapplied. ${ }^{43}$

However, this system has a few drawbacks. First, the GI protection system that is not unified will weaken its legal protection due to the possibility of overlapping GI marks. For instance, GI protection through a trademark will grant its owner private rights. Meanwhile, the GI registration through AQSIQ will endow public rights that can be used communally by its local community. ${ }^{44}$ Second, China's inability to build a strong brand image toward GI products will lead to unique, high-quality GI products becoming indistinguishable from its competitor. Third, a huge dependency between industrial actors and government has caused slow progress of innovation in the GI product enhancement. ${ }^{45}$ Fourth, the lack of cultural identity in GI brands due to the homogenization of product packaging. To cut the production budget, most of China's industrial actors would neglect the importance of unique packaging for their GI

41 Gang Cai, "Research on the Development and Management of Geographical Indications in Today's China" (2019) $4^{\text {th }}$ International Conference on Education and Social Development at 228.

42 Xiangjun Kong, et al., "Research and Cooperation on the Protection of China-ASEAN Geographical Indications under the TRIPS Agreement" (2017) 5:2 Advances in Economics and Business at 5l, DOI: $\langle 10.13189 /$ aeb.2017.050201

43 Ibid at 55.

44 Gang, supra note 41 at 229.

45 Ibid at 229-230. 
products. Hence, it will directly impact consumers' perception and contradict GI's original aim to promote natural resources and their geographical origin. ${ }^{46}$

In this practical context, GI in Indonesia is only outlined by one government body, the Ministry of Law and Human rights. Compared to China, a single regulatory body helps prevent any overlapping GI marks with other regulatory bodies. A unified protection system will also simplify the GI application process and management of the goods. It also will help the role distribution in every step needed to be taken. Indonesia also has a more substantial national branding impact than China. In terms of the GI goods marketization, an indigenous brand with a strong impact can create its niche and characteristic. A sample is branding strategies used in Indonesia's specialty coffee commodities that successfully create a tangible link between the goods and their origin. However, China's packaging homogenization to cut the production budget has given its GI goods a drawback. It is its incapability to distinguish itself from other goods in the same market.

\section{Australia}

Australia, a country in one single continent with numerous cultural heritage and abundant natural resources both from its Aboriginal Tribe ancestor and its unique climate, has also become one of the countries with the highest number of registered GI after European countries. Not only actively registering its GI, but Australia also designed a comprehensive GI protection system through certification marks and a sui generis system for wine products. Trademarks certification is regulated under the Trademarks Act 1995 and beneficial in maintaining product quality. Certification marks serve as marks symbolizes a fulfillment of certain standard and requirements from the designated products. Particularly for GI based products, one of the requirements that should be met is that the product needs to be closely related to the place where it originated. This connection can be in the form of a product's main ingredient, production process, or another unique trait associated with its origin. As an example, GI based cheese is intended to be registered should be made from local milk harvest from cows that have been bred in that area too. ${ }^{47}$

International Property Australia will examine the GI registration application to checked whether the product has met the requirements to be registered as a trademark. The application then will be forwarded to the Australian Competition and Consumer Commission (ACCC) to be examined thoroughly under the Competition and Consumer Law. After the examination phase is completed, the GI trademark application will be publicly announced. Other parties are given a chance to file any complaint or rebuttal toward that application if there is no rebuttal filed regarding a GI trademark application. Hence, trademarks will be registered as GI. Finally, after a GI application has been successfully registered, its owners will be granted a right to use it

46 Ibid.

47 IP Australia, "Geographical Indications", IP Australia (26 February 2019), online: <www.ipaustralia. gov.au> 
by themself or allowing other parties to do so. However, due to the GI name tagged and the trademarks, its owner and user should always maintain certain qualities and requirements to keep the GI product's reputational link. ${ }^{48}$

Australian sui generis system is explicitly applied for wine products and regulated under the Australian Grape and Wine Authority Act (AGW Act) introduced in 1994. This regulation implements the Australian-European Community Agreement on Trade in Wine (Wine Agreement). It later becomes the first milestone of the GI protection system through registration. Additionally, the current act has been revised and amended many times since its establishment. The Australian sui generis system has been proven to protect its GI based wine, both under the trademarks regime and AGW Act. Even a few wine brands registered under both laws, such as Pureness, with its trademark code $888055 .{ }^{49}$

Strict parameters for monitoring GI goods implemented by the Australian government are probably the key to success in Australian GI management. Insofar, in Indonesia, GI goods' quality control step is solely authorized by MPIG as the rights' proprietor. Compared to Australia, a set of certain standards should be fulfilled in order to be able to keep using the rights. Moreover, the collaboration between the IP office and Australian Competition and Consumer Protection will protect the consumer from possible GI infringement in the future. It will also help build GI goods' reputation quickly due to the strict regulation that should be passed to maintain the qualities. Unlike in China, Australia's approach by involving two wine products regulations bring advantages. Hence, as long as GI's application does not overlap with each other, a double protection system will build reliable protection for GI goods.

\section{GEOGRAPHICAL INDICATIONS' ADVANCEMENT AND UTILIZATION FOR SUSTAINABLE ECONOMIC DEVELOPMENT}

Indonesia's extensive GI potential has led the government to formed a sui generis law and system to preserve it from irresponsible parties' misappropriation. Under the Indonesian law regime, GI proprietorship is owned collectively by its local group owner. As stated in Article 53 (3) of Law No. 20 of on Trademarks and Geographical Indications, the parties who have rights to become GI applicant are an institution representing the local group in a certain area which is producing goods or products, and local government in the city or provincial level. ${ }^{50}$ This article explicitly stated the collective ownership of GI. The type of collectively owned right also indirectly obliged the government to actively participated in it, starting from mapping, registering, product, and quality control, to the final phase when GI products successfully transformed into export commodities. Public intervention from the government is

\footnotetext{
48 Ibid.

49 IP Australia. Recent developments in Australia in the field of Geographical Indications (Canberra: IP Australia, 2019)

50 The Indonesian Law, supra note 13 Art 53 Para 3.
} 
encouraged to achieve GI's intentional goal of safeguarding high-quality goods produced in a certain country area. ${ }^{51}$

However, the government's role in Indonesia's GI protection is only limited to the level of examining and legalizing the GI application. When the States approves the application, the local people as its owner are fully authorized for its management. ${ }^{52}$ Hence, the government's role in every GI project is crucial in managing GI products by setting specific standards and requirements that should be met by related parties and other needed steps that should be executed. First, the government needs to build a systematic, precise, and comprehensive GI protection system using collaboration between local and national government. Local governments can fully maximize their role by mapping the potential GI in their local region and cooperating with a research institute or university. This measure aims to research and register the potential GI founded from previous research collaboration, prepare a registered GI management model based on the products' classification through Regional Bodies, making a set of local regulation that covers each responsible parties' obligation, and to form a particular unit to manage GI and other general intellectual property. ${ }^{53}$ Meanwhile, the national government is urged to fully collaborate with related Ministers to participate in the GI empowerment project. ${ }^{54}$

Second, the designated potential GI should be registered legally from establishing the GI protection system and mapping. In the registration phase, the Book of Specifications (Buku Persyaratan) is a necessary material to assist the examining process of GI registration. The Book of Specifications itself contains; i) How is the product's unique characteristic correlates with its origin geographical and cultural condition; ii) The necessary process to produce GI goods starting from the production until it becomes ready-to-sell goods in the market; iii) quality control, monitoring, and labeling system that is used by communities owning geographical indications (Masyarakat Pemilik Indikasi Geografis, referred with MPIG). ${ }^{55}$

For instance, in the coffee sector, the Book of Specifications maintains coffee's quality. It monitors MPIG's role in running the production process. An impromptu inspection is always carried out to monitoring the farm's condition, producing tools,

51 Caroline L Goffic \& Andrea Zappalaglio, "The Role Played by the US Government in Protecting Geographical Indications" (2017) 98 World Development at 38, DOI: 〈http://dx.doi.org/10.1016/ j.worlddev.2016.08.017>

52 Claire Durand \& Stephanie Fournier, "Can Geographical Indications Modernize Indonesian and Vietnamese Agriculture? Analyzing the Role of National and Local Governments and Producers' Strategies" (2017) 98 World Development at 96, DOI: 〈http://dx.doi.org/10.1016/j.worlddev. 2015.11.022>.

53 Nizar Apriansyah, "Perlindungan Indikasi Geografis dalam Rangka Mendorong Perekonomian Daerah (Protection of Geographical Indications within the Scope of Improvement of Regional Economy)" (2019) 18:4 Jurnal Penelitian Hukum De Jure at 540, DOI: 〈http://dx.doi.org/10.3064l/dejure. 2018.V18.525-542>

54 Ibid.

55 Jeffrey Neilson, Josephine Wright \& Lya Aklimawati "Geographical Indications and Value Capture in the Indonesia Coffee Sector" (2018) 59 Journal of Rural Studies at 38, DOI: 10.1016/j.jrurstud. 2018.01.003> 
mill, and product storage warehouse to preserve specialty coffee quality and reputation. MPIG is obliged to monitor every related member on its production chain to create traceable coffee from its very first chain. MPIG is also authorized to issuing a certification document for every coffee lot that has passed the internal inspection conducted by them. ${ }^{56}$ Indonesian coffee is already well-known worldwide to the point of creating its niche market. Hence, GI based coffee management is already well implemented due to its long experience. However, this system can also be applied in other sectors such as agriculture and horticulture. The other issues commonly faced by the MPIG's inadequate financial capability hindered them from registering their potential GI. Third-party collaboration with private institutions will help address these issues as Bali does in Kopi Kintamani registration as Indonesia's first registered GI. In Kopi Kintamani registering project, the Indonesia research center and French research institute partnered with the local government to prepare the registration application of Kopi Kintamani Bali. Later, the head of the Subak Abian ${ }^{57}$ the organization joined and actively participated in the final phase of that project.

Third, assigning every parties' role after GI has been registered. Unlike a trademark, a certification mark uses in GI protection is owned by a third party such as the government or private institutions. This certification method aims to put a set of particular standards for GI products that should be fulfilled by the producers. As long as the producers or any GI user can pass the requirements, their right to use the GI cannot be nullified. For example, Florida Citrus certification that being hold by the Citrus Department of Florida State Government..$^{58}$ To manage GI thoroughly, collective action from every party is urgently needed. The government can assist the project by granting incentives to the MPIG, education and training program, and funding program to empowered the local's industry in this field. However, the final decision regarding transfer technology still depends on each producer. Hence, to raise MPIG's awareness to preserve and even increase their GI product's quality, a socio-economic analysis of MPIG should be conducted. .9

Additionally, government involvement should also carefully design to create an efficient policy. In GI management, it has been proven that the "top-down" scheme from the national government is not the best possible solution. Rather than implementing policy directly from the national level, decentralized power delegates to each local government that will result in a more approachable policy for the locals. Local governments' participation will also improve local producers' participation in the GI project by using various methods such as becoming a facilitator in negotiation between

56 Ibid at 39.

57 Subak Abian is a traditional organization specialized in dryland farming and commonly known as an agricultural, economic, religious organization located in Bali and still exists since long ago until present days. Accessed from: "Data Subak Abian di Kabupaten Karangasem, "Dinas Kebudayaan Kabupaten Karangasem (15th December 2017), online: 〈dishub.karangasemkab.go.id〉

58 Fabio Parasecoli, "Geographical Indications, Intellectual Property, and the Global Market," in Sarah May, et al., Taste, Power, Traditions-Geographical Indications as Cultural Property (Gottingen: Deutsche Nationalbibliothek, 2017) 13 at 17.

59 Durand, supra note 52 at 8. 
local producers and third-party. A successful negotiation will lead to better quality management due to local producers' continuous technology adaptation acquired from other parties. ${ }^{60}$ Other supporting factors that can be considered in involving local governments are i) Local Governments can actively participate in every phase of GI project management; ii) Local Governments are more capable when it comes to identifying important local actor in the production chain; iii) Local Governments are a better representation when it comes to representing and promoting their culture and local's involvement in it. ${ }^{61}$

Fourth, both national and local governments are obliged to create a competitive and efficient market condition for non-oil and gas commodities to strengthen market power by selling high-quality products to consumers. ${ }^{62}$ Due to its collective ownership, maintaining GI products' quality is not an easy task to be done. However, this obstacle can be solved by combining producers' self-control, MPIG's administrative control, and external control by DGIP National Experts Team. This control mechanism also should be equipped with rules and standards applied to whole GI users. ${ }^{63}$ This set of rules will guide every producer in preventing potential misappropriation, unfair competition, GI defamation, and preserving high-quality products' hence able to compete fairly in their niche market. Furthermore, other than using quality control, crafting a competitive GI product can also be achieved by giving special characteristics that distinguished it from its competitor. The differentiating mark usually forms a specific sign or logo. It symbolizes a certification mark and a product's identity so its consumers can easily recognize it. ${ }^{64}$

Fifth, in the case of third-party cooperation, a further agreement to regulating each party's responsibility is necessary to be prepared. Local Productive Agreements (LPA) is one of the agreement's types commonly used in Brazil when managing their GI. LPA is an agreement that categorizes economic, social, and political actors to collaborating in an economic project while maintaining their relationship as long as the agreement still be valid. In LPA, the territorial factor is a determining factor for the territorial agreement mark and a symbol indicating a trust's collaboration area. ${ }^{65}$ Additionally, there are three committees formed in the LPA implementation in Brazil. These committees are a superior board with the decision-making authority, working groups responsible for executing strategical plans into the project, and an advisory council

60 Ibid, at 9 .

61 Ibid.

62 Mas Rahmah, "The Protection of Agricultural Products Under Geographical Indication: An Alternative Tool for Agricultural Development in Indonesia" (2017) 22:2 Journal of Intellectual Property Rights at 95.

63 Ibid at 101 .

64 Delphine Marie-Vivien \& Estelle Bienabe, "The Multifaceted Role of the State in the Protection of Geographical Indications" (2017) 98 World Development at 4, DOI: 〈http://dx.doi.org/10.1016/j.worlddev.2017.04.035〉.

65 Marco Antonio Conejero \& Aldara DS. Cesar, "The Governance of Local Productive Arrangements (LPA) for the Strategic Management of Geographical Indications (GIS)" (2017) 20:1 Ambiente \& Sociedade at 294, DOI: 〈10.1590/1809-4422asoc20160010v2012017〉. 
consisting of representation from other private institutions. ${ }^{66}$ Generally, LPA has a role in supporting GI implementation and management by involving many parties on the decision-making level.

Sixth, the local and national governments should design promotion and marketing strategy by enhancing producers' ability to access the market directly. A direct partnership between producer and exporter will guarantee better market prices for a better-quality product. The essential activities that should be done are communicating through consumers continuously, and providing clear and precise GI products, increasing consumer trust toward the Indonesian GI product. For achieving the marketing and promoting phase successfully, the government, MPIG, and producers, who are MPIG's members, are obliged to promote the GI product individually and collectively. ${ }^{67}$

Seventh, in terms of GI legal enforcement, the government should address every GI misappropriation and infringement with possible punitive measures assertively. The national government is also authorized to impose certain sanctions as if any other intellectual property misappropriations. Like the trademark system, MPIG as the GI owner, can file a lawsuit toward their GI misappropriation case. Due to its collective proprietorship, the government is encouraged and recommended to intervene in its processes. ${ }^{68}$ This intervention can take the form of assisting in the investigation, facilitating expert opinion, and others.

Establishing a comprehensive and efficient GI protection system is one of the keys to achieving the GI's ultimate goal to sustain economic development. The socioeconomic factor and the partnership within related parties determine whether the GI project will be carried out successfully or failed miserably. It also will show whether a certain GI would fully impact the whole life sector of MPIG or only acts as a mere registered cultural heritage.

\section{CONCLUSION}

GI as one of the intellectual property sub-categories is closely associated with its geographical origin and local society's cultural heritage. GI's utilization will bring plenty of benefits such as protecting the cultural heritage, a tool for MPIG's socioeconomic development, adding local products, and promoting local culture widely. Indonesia's GI protection is regulated under the sui generis system, Trademark and Geographical Indications Law. However, the amount of registered GI in Indonesia is still considered low compared to Indonesia's abundant potential GI and natural resources. To efficiently protecting and utilizing Indonesia's GI as a tool for sustainable economic development, certain steps should be taken by the government. These steps are made by establishing a systematical, precise, and comprehensive GI registration

\footnotetext{
66 Ibid at 297.

67 Rahmah, supra note 62 at 101.

68 Vivien, supra note 64 at 6.
} 
system, and registering potential GI. In addition, the government should enhance each related party's role in GI management and creating a competitive and efficient non-oil and gas market condition. Then, it also should use LPA to regulating parties relationship in term of third-party partnership and Design intensive marketing and promoting strategy. In the end, the government may impose punitive measures assertively for every GI misappropriation and infringement case. Further empirical research in the future is needed to answer other unsolved problems, particularly in figuring real obstacles local communities faced that caused the low number of registered GI in Indonesia.

\section{ACKNOWLEDGEMENTS}

None.

\section{COMPETING INTERESTS}

The authors declare that they have no competing interests.

\section{REFERENCES}

Apriansyah, Nizar, "Perlindungan Indikasi Geografis dalam Rangka Mendorong Perekonomian Daerah (Protection of Geographical Indications within the Scope of Improvement of Regional Economy)" (2019) 18:4 Jurnal Penelitian Hukum De Jure, DOI: htttp:/dx.doi.org/10.30641/dejure.2018.V18.525-542〉.

Atsar, Abdul, Mengenal Lebih Dekat Hukum Hak Kekayaan Intelektual (Yogyakarta: Penerbit Deepublish, 2018).

Belletti, Giovanni, Andrea Marescotti \& Jean-Marc Touzard, "Geographical Indications, Public Goods, and Sustainable Development: The Roles of Actors' Strategies and Public Policies" (2017) 98 World Development, DOI: 〈https://doi.org/10.1016/j.worlddev.2015.05.004〉.

Blakeney, Michael, The Protection of Geographical Indications: Law and Practice (Cheltenham: Edward Elgar Publishing Limited, 2014).

Calboli, Irene \& Delphine Marie-Vivien, "One Size Does Not Fit All: The Roles of the State and the Private Sector in the Governing Framework of Geographical Indications" (2018) 24 The Cambridge Handbook of Public-Private Partnerships, Intellectual Property Governance, and Sustainable Development, DOI: 〈https://doi.org/10.1017/9781316809587.017).

CNN Indonesia, "Permintaan Ekspor Buah Naik Pesat Selama Pandemi Corona," CNN Indonesia (10 August 2020), online: 〈www.cnnindonesia.com〉.

CNN Indonesia, "Airlangga Sebut Buah-buahan Bisa Jadi Tumpuan Ekonomi RI," CNN Indonesia (10 August 2020), online: 〈www.cnnindonesia.com〉. 
Conejero, Marco A \& Aldara D.S. Cesar, "The Governance of Local Productive Arrangements (LPA) for the Strategic Management of Geographical Indications (GIS)" (2017) 20:1 Ambiente \& Sociedade, DOI: <10.1590/18094422asoc20160010v2012017>.

Donandi, Sujiana, Hukum Hak Kekayaan Intelektual di Indonesia - Intellectual Property Rights Law in Indonesia (Yogyakarta: Penerbit Deepublish, 2019).

Durand, Claire \& Stephanie Fournier, "Can Geographical Indications Modernize Indonesian and Vietnamese Agriculture? Analyzing the Role of National and Local Governments and Producers' Strategies" (2017) 98 World Development, DOI: 〈http://dx.doi.org/10.1016/j.worlddev.2015.11.022〉.

Gang Cai, "Research on the Development and Management of Geographical Indications in Today's China" in $4^{\text {th }}$ International Conference on Education and Social Development (Shenzen: ICESD, 2019).

Goffic, Caroline L \& Andrea Zappalaglio, "The Role Played by the US Government in Protecting Geographical Indications" (2017) 98 World Development, DOI: 〈http://dx.doi.org/10.1016/j.worlddev.2016.08.017〉.

Hananto, Pulung W.H \& Rahandy R.P., "The Urgency of Geographical Indication As A Legal Protection Instrument Toward Traditional Knowledge in Indonesia" (2019) 15:1 Law Reform, DOI: < https://doi.org/10.14710/lr.vl5il.23355〉.

IP Australia, "Geographical Indications," IP Australia (26 February 2019), online: 〈www.ipaustralia.gov.au〉.

Irawan, Candra, "Pendaftaran Indikasi Geografis Sebagai Instrumen Perlindungan Hukum Dan Peningkatan Daya Saing Produk Daerah Di Indonesia" (2017) Seminar Nasional Multi Displin Dan Call For Papers Unisbank Ke 3, DOI: 〈https://doi.org/10.11ll/jwip/12073〉.

Karangasem Regency, "Data Subak Abian di Kabupaten Karangasem," Dinas Kebudayaan Kabupaten Karangasem (15 December 2017) online: 〈dishub.karangasemkab. go.id〉.

Kizos, Thanasis, et al., "The Governance of Geographical Indications: Experiences of Practical Implementation of Selected Case Studies in Austria, Italy, Greece and Japan" (2017) 119:12 British Food Journal, DOI: 〈https://doi.org/10.1108/BFJ-012017-0037).

Kong, Xiangjun, et al., "Research and Cooperation on the Protection of China-ASEAN Geographical Indications under the TRIPS Agreement" (2017) 5:2 Advances in Economics and Business, DOI: <10.13189/aeb.2017.050201〉.

Lai, Jessica C, Indigenous Cultural Heritage, and Intellectual Property Rights: Learning from the New Zealand Experienced (Lucerne: Springer International Publishing, 2014).

Lukito, Imam, "Peran Pemerintah Daerah dalam Mendorong Potensi Indikasi Geografis (Studi pada Provinsi Kepulauan Riau)" (2018) 12: 3 Jurnal Ilmiah Kebijakan Hukum, DOI: 〈http://dx.doi.org/10.30641/kebijakan.2018.V12.313-330〉. 
Ministry of Law and Human Rights, "Tingkatkan Devisa Negara dengan Indikasi Geografis," Kementerian Hukum dan Hak Asasi Manusia (8 November 2016), online: 〈www.kemenkumham.go.id〉.

Ministry of Trade, "Infografis Perkembangan Perdagangan Luar Negeri," Portal Statistik Perdagangan (September 2020), online: 〈statistik.kemendag.go.id〉.

Neilson, Jeffrey, Josephine Wright \& Lya Aklimawati "Geographical Indications and Value Capture in the Indonesia Coffee Sector" (2018) 59 Journal of Rural Studies, DOI: <10.1016/j.jrurstud.2018.01.003〉.

Nofrida, Fifi, et al, Statistik Perdagangan Luar Negeri Indonesia Ekspor 2018, (Jakarta: CV. Pratama Persada, 2018).

Purba, Achmad Z.U, Hak Kekayaan Intelektual Pasca TRIPs (Bandung: PT. Alumni, 2011).

Rahmah, Mas, "The Protection of Agricultural Products Under Geographical Indication: An Alternative Tool for Agricultural Development in Indonesia" (2017) 22:2 Journal of Intellectual Property Rights.

Republika, "RI Didorong Daftarkan Produk Indikasi Geografis," Republika (8th July 2019), online: 〈republika.co.id〉.

Sarah May, et al., Taste, Power, Traditions-Geographical Indications as Cultural Property (Gottingen: Deutsche Nationalbibliothek, 2017).

Saputra, Rian, Adi Sulistyono \& Emmy Latifah, "Permohonan Internasional Sebagai Upaya Perlindungan Indikasi Geografis Indonesia Dalam Perdagangan Global ( Studi Peraturan Pemerintah Nomor 22 Tahun 2018)" (2019) 7:2 Jurnal IUS: Kajian Hukum Dan Keadilan, DOI: 〈http://dx.doi.org/10.29303/ius.v7i2630〉.

Sulkowski, Lukasz, "Covid-19 Pandemic, Recession, Virtual Revolution Leading to Deglobalization?" (2020) 12:1 Journal of Intercultural Management, DOI : $<10.2478$ /joim-2020-0029〉.

Tashiro, Ai, Yuta Uchiyama \& Ryo Kohsaka, "Internal Processes of Geographical Indication and Their Effects: An Evaluation Framework for Geographical Indication Applicants in Japan" (2018) 5:3 Journal of Ethnic Food, DOI: 〈https://doi.org/10.1016/j.jef.2018.07.004〉.

The Coffee Guide, "Trademarks versus Geographical Indications," The Coffee Guide: Trade Practices of Relevance to Exporter in Coffee Producing Countries (30th June 2012), online: 〈thecoffeeguide.org〉.

UGM, "UGM Expert: Indonesia Imperilled Recession If Government is Dilatory on Handling Covid-19", Universitas Gadjah Mada (16 July 2020), online: 〈ugm.ac.id〉.

Vivien, Delphine M \& Estelle Bienabe, "The Multifaceted Role of the State in the Protection of Geographical Indications" (2017) 98 World Development, DOI: 〈http://dx.doi.org/10.1016/j.worlddev.2017.04.035〉

Yunita, Primadiana, HAKI dan Masyarakat Ekonomi ASEAN (Malang: Cempluk Aksara, 2019). 
$300 \mid$ Geographical Indications in Trade Commodities for Promoting Sustainable Economic Development in Indonesia

This page intentionally left blank 